\title{
THE TECHNICAL PARAMETRS AND ROAD NETWORK IN THE JAKUBOWICE KONINSKIE VILLAGE
}

\author{
Antoni Grzywna ${ }^{1}$, Roman Rybicki' \\ Department of Environmental Engineering and Geodesy, University of Life Sciences in Lublin, Leszczyń- \\ skiego 7, 20-950 Lublin, Poland, e-mail: agrzywna@wp.pl
}

Received: 2017.03.13

Accepted: 2017.05.31

Published: 2017.07.01

\begin{abstract}
Parameters of agricultural transport network are an important element that affects the operating costs of farms. The proper conditions of the road network, suitable density and the quality should provide a opportune and efficient transport between home farm and some of the parcels. The article presents an evaluation of the agricultural road network in the village of Jakubowice Koninskie in the Niemce commune. An inventory of the study area was conducted, and the road density index, road extension index, and technical parameters (the width of the roads and the type of their surface) were determined. When the area of the village of 638 hectares and a total length of roads $35.44 \mathrm{~km}$ the road density index was $55 \mathrm{~m} \cdot \mathrm{ha}^{-1}$. Due to the surface the largest share in the structure of length are dirt and concrete roads.
\end{abstract}

Keywords: road of agricultural transport, technical parameters, road network

\section{INTRODUCTION}

In the farm operating, transport plays a huge role and its importance is steadily increasing. One of the most important elements of the organization of the village lands is the correct arrangement of plots, their size and proper density and arrangement of agricultural roads. The problem of the structure of the agricultural areas has an extensive literature [Hopfer et al. 1980, Pijanowski 1992]. By the agricultural production area we understand part of the surface of the earth involved in the process of agricultural production [Grzywna 1998]. The size of area and number of plots and their mutual location determined both: labor costs and road density. The size of the plot is varied according to the size of farms, land use, relief and means of transport [Przegon 2007]. As the optimal length of the plots was accepted 250-400 $m$ with length to width ratio 3-6: 1 while maintaining the availability of each land parcel to the road [Pijanowski 1992].

The main factors determining the development of infrastructure systems are population and jobs.
Most traffic loaded places usually are the centers of cities and main roads in the country. Average traffic in Lublin province was 2.711 vehicles per day. At the same time the most loaded roads are those that are the main communication routes of national and regional roads [GDDKiA 2013].

Length, layout and quality of agricultural transport roads are important elements of the assessment of farms agricultural expanse [Janus and Taszakowski 2014, Rybicki 2016]. Therefore, the roads used for agriculture transport should be assessed in terms of their suitability for agricultural transport, especially [Radziszewska and Jaroszewicz 2012]:

- when taking into perspective quantitative terms: degree of compaction of roads (Gd), the rate of elongation of roads (Ud), transportation-intensiveness $(\mathrm{T})$,

- when taking into perspective the quality: width, structure type,

- from the point of view of individual farms (easy access to all agriculturally used lands with habitat farms, the shortest distance from the buildings to the farms. 


\section{METHOD AND MATERIALS}

The aim of the study was to verify technical parameters and system of the road in the village of Jakubowice Konińskie. The basis for development were land registration map of 1:5000 scale (developed in 2014), topographic map in scale 1: 10000 (developed in 2014) and other data obtained from the municipality. After field verification of cartographic materials, quantitative and qualitative parameters of road network such as the width and type of structure road, degree compaction, transportation-intensiveness, the share of the area occupied by the road were determined. For the analysis of the distance and for presentation of the results QGIS computer program was used.

The study included Jakubowice Konińskie village in the commune of Niemce, bordering to the south with the city of Lublin and to the west with the Jastków commune. The village is situated in the area of Giełczewska Lofty [Kondracki 2002]. On the area of 638 hectares 300 houses, inhabited by 1000 people are located. This means the density of population about 150 persons per $1 \mathrm{~km}^{2}$. The discussed area is characterized by a slightly undulating terrain sculpture with the height difference of $20 \mathrm{~m}$. Land declines do not exceed $10 \%$ so this area is attractive for agricultural production. At the same time. due to the direct vicinity of Lublin a strong urban pressure is seen. Because of this, there is high density of houses in some places making compact residential estates. Moreover, the nature of land use is strongly determined by the topography, soils grading value and ownership. There are mainly loess soils with a high content of silt, susceptible to water and wind erosion. They belong to the most quality soil rating. In the structure of use arable land occupies $78 \%$ of the area. Farm lands and building plots are heavily fragmented, and parcels are located in a mutual chessboard. Ownerships are still based on individual farms with an average area of $5 \mathrm{ha}$. The average area of the agricultural parcel is $1 \mathrm{ha}$, while building plot is 0.1 ha [Strategy 2012].

\section{ANALYSIS OF RESULTS}

Roads for agriculture transport can be evaluated according to various criteria [Dzikowska 2008]. The most important among them are the right of ownership, surface type and technical parameters. In terms of the ownership, roads can be divided into public (most often municipal) and private (access roads). Due to the surface we can distinguish roads with hard surfaces (asphalt, concrete, crushed stone) and dirt roads [Dz. U. 1985.14.60; Dz. U. 1999.43.430].

For the characteristics of the existing road network, the analysis of the technical condition of the roads and road system, depending on their ownership should be conducted. For this purpose technical parameters (Table. 1) and arrangement of agricultural roads (Fig. 1) were presented.

The basic indicator describing the road network used for agricultural transport in quantified terms and used to evaluate the status of land fragmentation is a degree of road compaction (Gd). It is defined as the ratio of road length in meters $(l d)$ to a supported area in hectares $(P)$ [Akińcza and Malina 2007]. The most advantageous road density is $35 \mathrm{~m} \cdot \mathrm{ha}^{-1}$ [Jasiński and Nowak 1986]. Wherein the minimum road maintenance costs and parcels as well as their distance from the habitat are obtained in the range of 30 to $44 \mathrm{~m} \cdot \mathrm{ha}^{-1}$ [Akińcza and Malina 2007]

For the village of Jakubowice Konińskie the total length of the roads was $35.44 \mathrm{~km}$. Considering the surface of the village (638 ha) the road density ratio was $55 \mathrm{~m} \cdot \mathrm{ha}^{-1}$. Such a high value of this ratio due to the high fragmentation of agricultural parcels and necessity to ensure access of each one to the road. These plots in the past were divided into several parts and converted into building plots. On the land records map mostly long and narrow plots, measuring even $300 \mathrm{~m}$ by $10 \mathrm{~m}$, are visible. Equally disturbing is the presence of parcels of area less than 0.1 ha in dense development area along the main road towards Lublin (Figure 1).

Table 1. Technical parameters of existing roads in Jakubowice Konińskie village

\begin{tabular}{|c|c|c|c|c|}
\hline Type of the road & $\begin{array}{c}\text { Actual width of the } \\
\text { roadway } \\
(\mathrm{m})\end{array}$ & $\begin{array}{c}\text { Required width of the } \\
\text { roadway } \\
(\mathrm{m})\end{array}$ & $\begin{array}{c}\text { Total width of the road } \\
(\mathrm{m})\end{array}$ & $\begin{array}{c}\text { Area occupied by the } \\
\text { road } \\
\left(\mathrm{m}^{2}\right)\end{array}$ \\
\hline Voivodeship & 5.5 & 6.5 & 8.0 & 25600 \\
\hline Commune & 4.0 & 5.0 & 6.0 & 87540 \\
\hline Rural & 3.0 & 3.0 & 5.0 & 14250 \\
\hline Rural & 2.5 & 3.0 & 2.5 & 44400 \\
\hline Total & - & - & - & 141790 \\
\hline
\end{tabular}




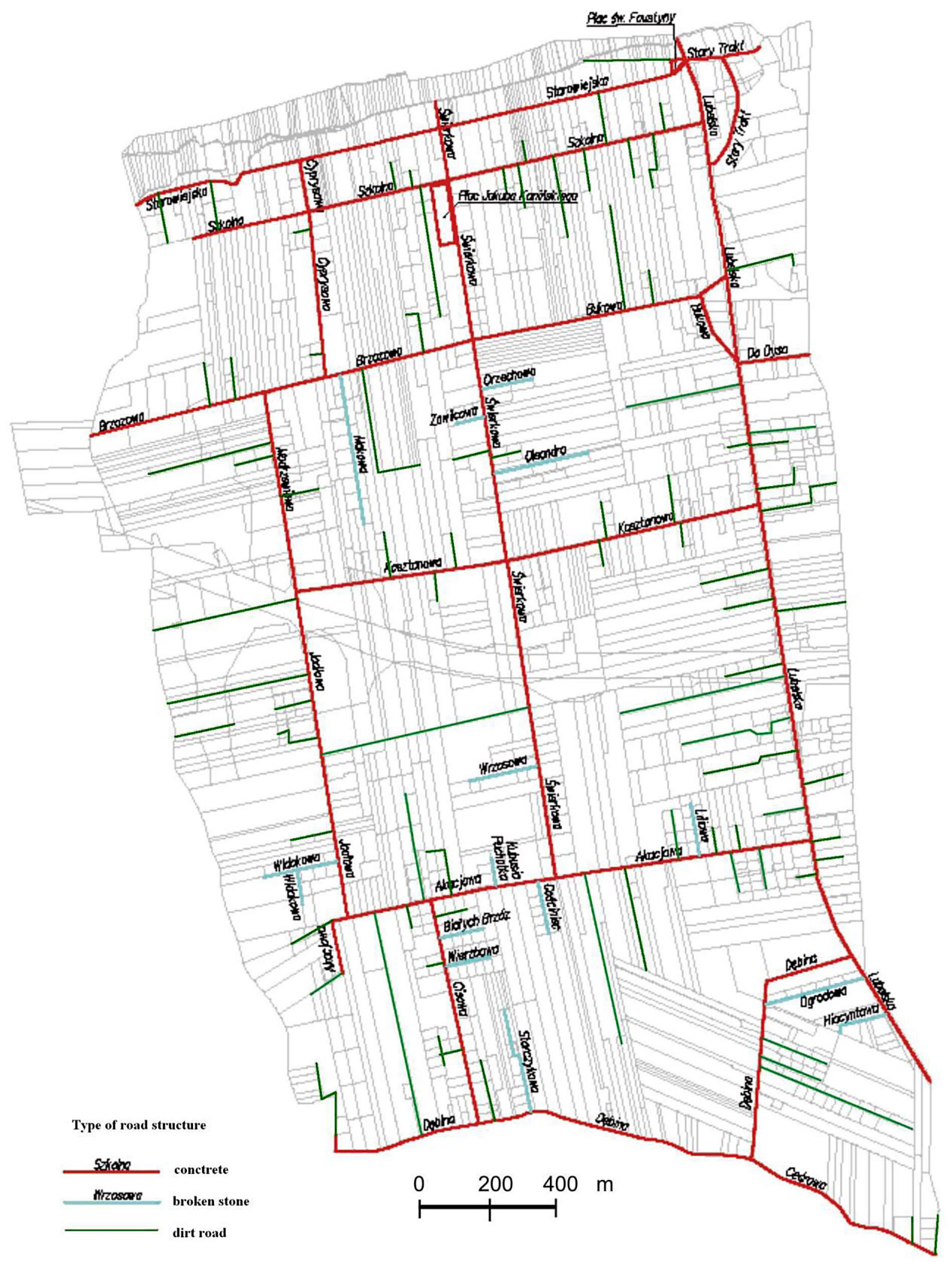

Figure 1. The roads system and land parcels

Another indicator for evaluating the roads is indicator of roads extension. It is calculated as the ratio of the length of roads and ratio of crossing time lengthening $(t)$ dependent on the type of road surface. Due to the structure, dirt roads constitute the largest share in total length of roads . Their total length amounts to $14.8 \mathrm{~km}(41.7 \%$ of total length of roads). Slightly smaller proportion are roads with concrete structure - their total length is $14.6 \mathrm{~km}(41.2 \%$ of total length of roads). A fairly 
small share (less than 10\%) are roads with asphalt and broken stone (Table 2). Asphalt pavement road in the village is only the Lublin street being a part of the voivodeship road No. 747. Except that roads only short access roads to the complex of built plots are made with crushed stone. The calculated average transportation-intensiveness indicator of roads amounting to 3.1. In case of rural areas it is relatively low value. For typically agricultural areas transportation-intensiveness ratio is often approximately 4.0 [Grzywna 1998, Nowocień and Wawer 2007].

A significant element in correct formation of the farms agricultural expanse in eroded areas is adaptation of the agricultural roads to the terrain, hardening their surface and construction of drainage facilities [Józefaciuk et al. 2000, Fiedler et al. 2014]. Properly marked and paved roads in addition to plays not only economic but also an antierosion function [Woch 2001, Więckiewicz i in. 2004]. Roads on the analyzed area occupy $2.2 \%$ of the village area. This is a typical amount for agricultural lands.

Besides, an important quality indicator of roads is the width of the road. Table 2 shows the actual width of the roadway and widths required by legislation [Dz. U. 1999.43.430]. It was found that in the case of voivodeship and commune roads widths are smaller than is required. Less than the required value of width of the voivodeship road roadway probably due to the fact that the road was located at the place of the old equestrian tract. Moreover, until the end of the twentieth century along this route the fence was built directly at the sidewalk or drainage ditch. Therefore, in some sections it is currently not possible to widen the road. Contrast situation is observed in the case of commune roads. Most of them were modernized in the 21-th Century. Along these one of the fences was localized at a distance 3-5 $\mathrm{m}$ from the road. Nevertheless, the roadway is narrower by about 0.5 to $1.5 \mathrm{~m}$ than required. This may result from a very small movement of vehicles and from savings made by the municipality (road manager) during the construction of the road.
The soils found in Jakubowice Konińskie (loess soils) are classified as low heaving. The water table occurs at a depth more than $2 \mathrm{~m}$. This creates good conditions for water. Due to soil and water conditions base ground of road construction is classified as a G3 category of carrying capacity (average conditions).

\section{CONCLUSIONS}

1. The study included Jakubowice Konińskie village belonged to the commune of Niemce bordering to the south with the city of Lublin and to the west with the Jastków commune. Quantitative and qualitative parameters road network such as the width and type of surface, degree compaction, transportation-intensiveness, the share of the area occupied by the road were determined.

2. For the village of Jakubowice Konińskie. the total length of the roads was $35.44 \mathrm{~km}$. Considering the surface of the village (638 ha) the road density ratio was $55 \mathrm{~m} \cdot \mathrm{ha}^{-1}$. Such a high value of this ratio is due to high fragmentation of agricultural parcels and necessity of ensure everyone's access to the road. The calculated average transportation-intensiveness of roads amounting to 3.1. In the case of rural areas it is relatively low value.

3. Due to the structure, the largest share in total length of roads have dirt roads. Their total length amounts $14.8 \mathrm{~km}(41.7 \%$ of total length of roads). Slightly smaller proportion are roads with concrete structure $-4.6 \mathrm{~km}$. Roads on the analyzed area occupy $2.2 \%$ of the village area. This is a typical amount for agricultural lands.

4. Existing road transport network is characterized by a desirable ladder system of paved roads. The high density rate results mainly from the excessive length of the structure dirt roads, which are access roads to fragmented plots. Also in terms of strengthening of surface analyzed system is characterized by a high proportion of paved roads (all main roads). Roads

Table 2. Extension type of the road

\begin{tabular}{|c|c|c|c|c|}
\hline Type of the road & Type of road structure & Lenght of roads & Indicator of transport & Extension road \\
\hline Voivodeship & Asphalt & 3200 & 1.0 & 3200 \\
\hline Commune & Concrete & 14590 & 1.5 & 21049 \\
\hline Rural & Broken stone & 2850 & 3.4 & 9690 \\
\hline Rural & Dirt road & 14800 & 5.1 & 75480 \\
\hline Total & - & 35440 & 3.1 & 110419 \\
\hline
\end{tabular}


should be assessed the worst in terms of their width of road surface. This parameter is very often less up to $1 \mathrm{~m}$ from the normative value (in some sections there are even difficulties in passing vehicles).

\section{Acknowledgements}

Pracę dofinansowano ze środków Wojewódzkiego Funduszu Ochrony Środowiska i Gospodarki Wodnej w Lublinie.

\section{REFERENCES}

1. Akińcza M., Malina R. 2007. Geodezyjne urządzanie terenów rolnych. Wykłady i ćwiczenia. Wyd. Uniwersytetu Przyrodniczego we Wrocławiu.

2. Dzikowska T. 2008. Jakość dróg transportu rolnego - propozycja zasad ustalania kolejności modernizacji. Infrastruktura i ekologia terenów wiejskich, 3, 71-82.

3. Fiedler M., Antkowiak M., Sojka M. 2014. Analiza przestrzennego układu sieci dróg i cieków w gminie wiejskiej. Inżynieria Ekologiczna, 39, 51-61.

4. Generalna Dyrekcja Dróg Krajowych i Autostrad (GDDKiA). 2014. Raport o stanie technicznym sieci dróg krajowych na koniec 2013 roku.

5. Grzywna A. 1998. Charakterystyka dróg rolniczych w koncepcji zagospodarowania wsi Lipnik. Zeszyty Naukowe AR w Krakowie, sesja naukowa, 59, 275-282.

6. Hopfer A., Kobyłecki A., Żebrowski W. 1980. Kształtowanie sieci dróg na terenach wiejskich. PWRiL, Warszawa.

7. Janus J., Taszakowski J. 2014. Wybrane parametry sieci dróg transportu rolniczego w powiecie dąbrowskim w aspekcie urządzeniowo-rolnym. Infrastruktura i ekologia terenów wiejskich, 3, 1031-1042.

8. Jasiński J., Nowak A. 1986. Punktowa ocena stanu przestrzennego urządzania wsi o dominacji gospodarki indywidualnej. Zeszyty Naukowe Politechniki Warszawskiej, Geodezja, 26, 3-31.

9. Kondracki J. 2002. Geografia regionalna Polski. PWN Warszawa.

10. Nowocień E., Wawer R. 2007. Analiza przestrzenna sieci dróg rolniczych na przykładzie obszaru zlewni cieku Mielnica. Roczniki Geomatyki, 5(2), $65-72$.

11. Pijanowski Z. 1992. Analiza stosowanych długości uprawowych oraz ustalenie optymalnej długości działek i gęstości dróg rolniczych w Polsce południowej. Zeszyty Naukowe AR w Krakowie, rozprawa habilitacyjna.

12. Przegon W. 2007. Ochrona środowiska w projektach scaleniowych gruntów. Czasopismo Techniczne, 7, 269-275.

13. Radziszewska W., Jaroszewicz J. 2012. Ocena istniejącej sieci dróg transportu rolnego na obszarze wsi poddanej pracom scaleniowym. Acta Scientarum Polonorum - Geodesia et Descriptio Terrarium,11(3), 17-34.

14. Dz. U. 1999.43.430. Rozporządzenie Ministra Transportu i Gospodarki Morskiej z dnia 2 marca 1999 r. w sprawie warunków technicznych jakim powinny odpowiadać drogi publiczne i ich usytuowanie.

15. Rybicki R. 2016. Assessment of the agricultural road network in the Wola Idzikowska village resulting from land consolidation. Infrastruktura $\mathrm{i}$ Ekologia Terenów Wiejskich, 4, 1257-1268.

16. Strategia Rozwoju Gminy Niemce na lata 2009-15. Lublin 2008. www.niemce.pl

17. Dz. U. 1985.14.60. Ustawa z dnia 21 marca 1985 r. o drogach publicznych,.

18. Więckowicz Z. Akińcza M. Dzikowska T. 2004. Dobór mierników oceny zapotrzebowania na prace urządzenioworolne. Zeszyty Naukowe AR we Wrocławiu, 464, 309-320.

19. Woch F. 2001. Optymalne parametry rozłogu gruntów gospodarstw rodzinnych dla wyżynnych terenów Polski. Pamiętnik Puławski,127, 1-105.

Pracę dofinansowano ze środków Wojewódzkiego Funduszu Ochrony Środowiska i Gospodarki Wodnej w Lublinie. 